refugees who want to return to Monrovia. After several requests from the UNHCR, Charles Taylor has formed a one-man repatriation commission that has no facilities to operate. Despite IGNU's efforts to repatriate all refugees before elections are held, it is unlikely that a mass repatriation will take place before a political settlement is achieved. However, there can be no settlement until fair and free elections are held.

\section{Conclusions and Recommendations}

As with most refugee situations, the Liberian refugee crisis can best be solved through voluntary repatriation. The longer the refugees stay in asylum countries, the more difficult the process of repatriation and reintegration will be. The absence of a recognized government should not undermine repatriation efforts. International organizations should adapt to unusual situations and negoti-

\section{As with most refugee situa- tions, the Liberian refugee crisis can best be solved \\ through voluntary repatriation. The longer the refugees stay in asylum countries, the more difficult the process of repatria- tion and reintegration will be.}

ate with de facto governments to resolve refugee crises. The protection of refugees/returnees should be discussed in all peace talks, and organizations responsible for the protection of refugees should advocate that cause. In a situation where the political conflict is unresolved but where there is no military confrontation-as is the case in many counties in Liberia-repatriation is possible. The system, however, has to be flexible enough to allow for assistance in such circumstances and to organize mass repatriation to areas of relative tranquillity without formal agreement by governments. The most important factor is to guarantee the protection of returnees. This can be achieved through negotiations with the ruling factions of the areas to which the refugees wish to return.

\title{
Confronting the Future: The Effects of the Repatriation Program on a New Generation of Burundi Refugees
}

\author{
Marc Sommers
}

The goals of this paper are threefold: to provide context for the voluntary repatriation program for Burundi refugees in Tanzania; to consider some assumptions inherent within it; and to describe some of the effects of the plan on refugees, particularly on members of the younger generation. The views are based upon preliminary data analysis and should be considered as such.

\section{An Overview of the Voluntary Repatriation Program}

Burundi nationals have now lived as refugees for twenty years in Tanzania. Their population now numbers 155,000 officially, but is probably far more than that in reality. They have lived for two decades in Tanzania without the rights of citizenship and represent the survivors of the 1972 conflict in Burundi, which has been variously described as "ethnic genocide" (Lemarchard and Martin 1974) and "the Hutu slaughter" (Chretien 1990) of up to 200,000 ethnic Hutu (Weinstein and Schrire 1976). Significantly, the majority of the refugee population are either too young to remember 1972 or were born afterwards in a Tanzanian refugee settlement.

Late in 1991, a series of earlier meetings in Tanzania, Burundi and Switzerland produced a repatriation plan for these refugees. The governments of Burundi and Tanzania joined with UNHCR to announce a coordinated plan for offering refugees three options regarding their future. They can either return to Burundi, elect Tanzanian citizenship or maintain their refugee status in Tanzania.

Marc Sommers is with Boston University's Department of Anthropology and is currently writing his Ph.D. dissertation based on research in Tanzania on Burundi refugees.
The initiative is underway. Delegates from the three Burundi refugee settlements went to observe conditions in Burundi and Tanzanian officials, led by Augustine Mrema, the minister for Home Affairs, have also toured there. UNHCR should have already completed a census of Burundi refugees and will now try to accommodate each refugee's choice.

The information refugees have received about each option seems contradictory. The Tanzanian and Burundi governments have tried to pursuade refugees that conditions in Burundi are stable and peaceful, and that they are welcome to return. Approximately 20,000 refugees have already quietly returned on their own. Yet opposition parties with a presence in the settlements suspect trouble and provide stories to support their claims. Palipehutu, the largest opposition party, has declared multiparty elections in Burundi a prerequisite for repatriation. The Burundi government considers it an outlaw organization.

Both sides are vigorously trying to influence the refugees' decision. While the Burundi government attempts to induce refugees to return, Palipehutu and other opposition party members hope they remain in Tanzania. The environment surrounding the refugees' decision is fluid and charged.

\section{Two Divisions among Burundi Refugees in Tanzania}

Much of the literature on Burundi nationals divide the population into two predominant groups: the Tutsi and the Hutu and evaluates conflicts between them. This implies that Burundi society can be understood by examining the interplay between ethnic Tutsi and Hutu. The accepted cause of the extraordinary violence of 1972 is ethnic conflict; that the 
problem arose from tensions between the ruling Tutsi, who represent a mere 14 percent of the population, and the Hutu majority, who represent 85 percent. A third group, the Twa, comprise the remaining one percent. Indeed, all of the officials I interviewed in Dar es Salaam and Geneva at UNHCR and Tanzania's Ministry of Home Affairs cited ethnic conflict as the source of trouble.

While examining Burundi's problems along a Hutu-Tutsi axis is not inaccurate, it is inexact and misleading. The government of Burundi may indeed be dominated by Tutsi, but primarily those from one segment, the Hima (see Lemarchand and Martin 1974). In addition, the issue of ethnic identity in both Rwanda and Burundi is contentious: an examination of thelively debate between Chretien and Lemarchand, for example, illuminates the conflicting viewpoints.

Butmore important, the term "Hutu" also bears the general connotation of "Bantu." Findings in my research suggest that distinct Burundi refugee groups unify themselves as Hutus by their shared suffering at the hands of the Tutsi-dominated Burundi government (see Malkki 1989). Furthermore, refugees, particularly those with a political agenda, often highlight the Hutu-Tutsi division in descriptions to outsiders because it facilitates the impression of refugee solidarity. Because of this, refugees who identify splits within the refugee population, especially to nonrefugees, may invite trouble from other refugees. The information is volatile.

Yet two divisions that are very meaningful to many if not most refugees course beneath the outward perception of Hutu unity. Each of these divisions refers to refugee society. Refugees can divide themselves into separate groups along regional or class lines, which indicate differences among them. The ethnic Hutu-Tutsi division, on the other hand, refers to life in Burundi, not Tanzania.

During my interviews with refugees in Tanzania in 1991-92, many privately described a rift dividing all refugees into two regional groups. The Imbo are those who come from the coastal lowland areas along Lake Tanganyika. A mixture of smaller regional groups comprise all refugees from the southern highland areas of Burundi, the Banyaruguru, meaning, the refugees explained, "highland people."

While nearly all Burundi refugees come from southern Burundi (together with the Tutsi Hima rulers), the significance of this distinction may have taken hold only after entering Tanzanian refugee settlements. In interviews, members of each group communicate suspicion and even hostility towards the other, and described cultural and social differences between the two. Many endow deep meaning, for example, to the food preferences of each group: fish and ugali (stiff porridge) made from cassava for the Imbo; beans and maize-based ugali for Banyaruguru. Intermarriage, some refugees told me, is strictly prohibited by their parents. To refugees, the term "Hutu" often connotes purity and goodness, while "Tutsi" may connote per-

\section{One cannot be sure how refugees will respond to the repatriation plan until they are ultimately called to act.}

ceived evil oppressors. Privately castigating the other group for intermarrying with Tutsi and for not experiencing as much suffering in 1972, self-described Imbo and Banyaruguru each claim to be the "true" Hutu and thus the rightful owners of authority and power in Burundi.

The second division, which is between educated and uneducated refugees, separates refugees into two classes. For most Burundi refugees, an "educated" refugee is anyone with at least one year of secondary school education. This definition is highly charged with meaning, for the Burundi government used it in 1972 to target educated Hutu for elimination (see Greenland 1974, 1980; Weinstein and Schrire 1976). They apparently considered all members of this group as potential leaders of the opposition.

Refugees with primary education, who comprise the overwhelming majority of Burundi refugees, accord respect to university-educated refugees. They may also resent them. Educated refugees sometimes assume that they are the leaders and spokespeople for all Burundi refugees. Some even refer to the lesser educated as "little people."

The legacy of the 1972 campaign against educated Hutu entered Tanzania with the refugees, making the role of educated refugees critical to understandingBurundi refugee society. Whilemany Burundi refugees seem to recognize Imbo and Banyaruguru as distinct and possibly enemy groups with separate cultures and dialects, educated refugees may favour educational accomplishment over regional distinction. The refugee perspectives that outsiders, notably UNHCR, receive are usually volunteered by university-educated refugees. And since many may also express a political agenda, officials might assume that most refugees are equally politicized. I have not found this to be true.

\section{Recent Events and Refugee Responses to the Three Options}

Refugee concerns about the repatriation plan radically increased when Tanzania's minister for Home Affairs announced last March that refugees had three months to decide whether to repatriate or become Tanzanian citizens. He later expressed concern that a "second Burundi" might arise within Tanzanian borders.

Minister Mrema's dramatic ultimatum, proclaimed in newspaper headlines and over the radio, was never upheld, but it effectively forced refugees to realistically reconsider their aspirations. The fact that Mrema did not immediately mention the third option in the UNHCR-sponsored plan-that of remaining with refugee status-made many refugees anxious. Minister Mrema soon admitted that refugees could retain their refugee status, but this was mentioned in the English-language newspaper. Few refugees can read English.

How has this repatriation plan affected the aspirations of a new generation of Burundi refugees? The answer is complex, and my commentary here should be taken a brief, informal sketch of the responses of some refugees to the current situation. Burundi refugee life is 
rife with rumour and fear, which feed on each other. One cannot be sure how refugees will respond to the repatriation plan until they are ultimately called to act. The consequences of each alternative are dramatic, and so the choice to delay action is hardly surprising.

My findings reflect data gathered in Dar es Salaam over the course of twenty months. I left Tanzania this past July before the repatriation plan entered the implementation stage. Initial movements, however, had already begun. Reports on the condition of fellow refugees who had already repatriated varied widely. I heard rumours of repressive tactics by the Burundi army and stories that many had already returned to Tanzania. However, I also heard stories of the peaceful existence of returnees. I could not substantiate any of this. The picture presented by UNHCR and the Tanzanian government was that the Burundi government had begun to peacefully integrate returnees.

My research centred on the lives of young Burundi refugees in Dar es Salaam. Most reacted to the prospect of repatriation by avoiding thinking about it. This reflects their uncertainty about a homeland they have either never seen or cannot recall, but have heard fearful stories about. Indeed, many refugees I spoke with, young and old, seemed to be taking a wait-and-see attitude, saying that they would like to wait perhaps three years to discover how those refugees who have chosen to return have fared. A smaller number of refugees, notably educated ones, seek to retain refugee status in Tanzania for a prolonged period. From their perspective, returning could mean arrest or worse. Some young refugees I interviewed said that their decision was up to their parents. If their mother and father would return, then they would follow. A few declared that older refugees might even return alone to Burundi regardless of what occurred there. Elders, they reported, believe it is better to die at home than continue their refugee existence. Finally, becoming a Tanzanian citizen seemed unimaginable to many refugees, for it would mean relinquishing one's Burundi identity and risking harsh re- proach from other refugees. A significant number, however, may privately choose naturalization at a later date.

\section{Final Comments}

Burundi refugees fear retaliation from the Burundi army. Many perceive the Tutsi-dominated army as a force separate from the government and the greatest danger to successful repatriation. Reforming and integrating the army may be politically difficult to resolve in Burundi, but is necessary to ensure peace.

Most refugees are farming people with little education. Many I spoke with seem suspicious of all politics and regard peace and not political pluralism their primary concern. They told me that if the current government remained but the army approached a representative mixture of Hutu and Tutsi personnel, they might be sufficiently satisfied and repatriate.

Many foreign nongovernmental officials have told me that refugees would be better off if they remained in Tanzania because Burundi has a high population density and Tanzania does not. Yet significantly, not one refugee ever expressed this concern to me. How will this difference in perspective between officials and refugees affect the resettlement process?

Nonetheless, if 94,000 Burundi refugees choose to repatriate, as the planners have publicly predicted, is there sufficient land to resettle them all in rural Burundi? Unofficial estimates suggest that returnees might receive less than half the 5-8 hectare allotment refugee households receive in the Tanzanian settlements. Indeed, land shortages already seem to be presenting difficulties for the resettlement process. If land shortages continue, are there provisions and support to retrain returnees for nonfarming work?

Finally the critical question: have sufficient measures been undertaken to ensure success for the repatriation plan? Burundi's current president, Major Pierre Buyoya, has taken decisive steps to reform the ethnic constitution of the government, but are they sufficient? The legacy of the 1972-73 violence remains and some sources report sporadic violence and detentions in Burundi, offering, perhaps, dread signs of another tragedy. What role will Palipehutu and other opposition parties play in Burundi's future? Could intensified population pressure caused by resettling returnees in rural Burundi exacerbate social tensions and ignite conflict? And what efforts can all interested parties, including Western governments with regional influence--such as Belgium, France and the United States-make to create a stable, peaceful future in Burundi? 圆

\section{References}

Chretien, Jean-Pierre. 1990. "Burundi: Social Sciences Facing Ethnic Violence." A Journal of Opinion 19, no. 1:38-40.

1991. "Burundi: Le metier d'historien: Querelle d'école?" Canadian Journal of African Studies 25, no. 3:450-67.

Greenland, Jeremy. 1974. “The Reform of Education in Burundi: Enlightened Theory Faced with Political Reality." Comparative Education 10, no. 1:57-63.

1980. Western Education in Burundi 1916-1973: The Consequences of Instrumentalism. Brussels, Belgium: Les Cahiers du CEDAF, 2-3, 1980.

Lemarchand, Rene. 1980. "Ethnic Genocide." AQuarterly Journal of Africanist Opinion 10, no. 1-2:54-61.

1989. Burundi: The Killing Fields Revisited." A Journal of Opinion 18, no. 1:22-28.

1990. "Response to Jean-Pierre Chretien." A Journal of Opinion 19, no. 1:41.

1991. "Réponse à Jean-Pierre Chretien." Canadian Journal of African Studies 25, no. 3 .

Lemarchand, Rene, and David Martin. 1974. "Selective Genocide in Burundi," Report no. 20. London, England: The Minority Rights Group.

Malkki, Liisa Helena. 1989. "Purity and exile: Transformations in Historical-National Consciousness among Hutu Refugees in Tanzania." Unpublished dissertation, Harvard University.

Weinstein, Warren, with Robert Schrire. 1976. Political Conflict and Ethnic Strategies: $A$ Case Study of Burundi. Syracuse, New York: Foreign and Comparative Studies/ Eastern Africa XXIII, Maxwell School of Citizenship and Public Affairs, Syracuse University. 